\title{
Necessity, Desirability and Importance of Ecological Agriculture in the Context of Medicinal Plants Cultivation
}

\author{
Vasilica ONOFREI ${ }^{1 *}$, Gabriel-Ciprian TELIBAN ${ }^{1}$, Christiana Brigitte BALAN ${ }^{2}$, Iulian ROPOTOAIA ${ }^{4}$, \\ Alexandra - Andreea BUBURUZ ${ }^{3}$, Roxana-Alexandrina CLINCIU -RADU ${ }^{1}$,Teodor ROBU ${ }^{1}$ \\ ${ }^{1}$ University of Agricultural Sciences and Veterinary Medicine, Faculty of Agriculture, Iaşi, Romania \\ 2"Al.I. Cuza" University, Faculty of Economics and Business Administration, Iasi \\ ${ }^{3}$ Agricultural Research - Development Station Secuieni - Neamt, Romania \\ ${ }^{4}$ Sociologist \\ *corresponding author, e-mail: redactor_sef@yahoo.com
}

Bulletin UASVM series Agriculture 73(1)/2016

Print ISSN 1843-5246; Electronic ISSN 1843-5386

DOI 10.15835/buasvmcn-agr: 12015

\begin{abstract}
In recent years, the ecological farming began to gain an increasingly higher importance, due to the increase of areas cultivated in ecological system and of the number of producers and consumers. This paper aims at presenting in a concise manner the most important considerations about organic farming in the context of medicinal plant cultivation. By choosing as a basic research method the observation and the study of literature, an overview on it will highlight the main aspects regarding the unconventional farming systems, the history and the variants of the ecological farming concept, organic agriculture trends worldwide and in Europe, the state of ecological agriculture in Romania, OA's principles and perspectives of improving life quality by complying with them, the requirements for the organization of an ecological farm, the conversion to an organic farming, labelling of organic products, the quality and marketing of organic products. Also will elaborate an analysis of the determinant conditions of the promotion of ecological medicinal and aromatic plants production, represented by the consumers' perception, attractiveness and interest. The analysis will require to carry out a sociological study that will involve the survey method. The attitude towards organic production is revealed through questions related to the opinion about medicinal plants from spontaneous or cultivated flora, and also to the consumption preferences in the form of tea, infusions, natural products, cosmetics, packaging and presentation style. The main questions that define the tastes are related to herb consumption rate, the production of medicinal plants by individuals and/or farmers, plant type (ecological culture or spontaneous flora, Romanian or from import).
\end{abstract}

Keywords: conversion to organic farming, ecology, ecological agriculture, medicinal plantsphytotherapy

\section{INTRODUCTION}

Enriching the knowledge regarding the role of some characteristics and indicators of the biological cultivation techniques in higher yields and quality production can help increase the chances of extending the cultivation areas of medicinal and aromatic plants and creating some technologies with improved performance
Organic farming really flourished during the 80 s when new production model and the consumer interest in these products has continued to grow, so in most European countries and in other countries like USA, Canada, Australia and Japan. We are now witnessing a significant increase in the number of producers and a start-up initiatives in the organic products processing and marketing 
field. This context favorable to the development of organic farming is due, largely, to the consumer care to see exhibited healthy products and better respect the environment. In parallel, the official administrative services gradually resorting to the recognition of organic farming by putting it into research topics and adopting an appropriate legislation in this sector (for example, in Austria, France, Denmark).

On the other hand subsidies are granted both nationally and regionally, by some Member States of the profit from this type of farming.

The idea of an ecological agriculture arose early twentieth century, when heavily industrialized society began to replace the rural and traditional one.

The first mention of organic farming in Europe dates back to the beginning of 1924, when Rudolf Steiner argues first courses on farms converting to this type of agriculture.

The 1991, however officially marked the interest in organic farming through publication in the Official Journal of the European of the 2092/1991 Union Regulation concerning the products and food production, processing and packaging to match the name organic.

In practice, in Europe, chronologically were differentiated three current, parallel with the intensive agriculture: biodynamic, organic and biological.

The variants of biological agriculture given that all the unconventional farming systems (especially the sustainable agriculture system) were included under one name, respectively biological agriculture.

Davidescu D. and Davidescu V. (1994) conducted a presentation of the biological variants depending on how compost is prepared.

The term of biologic agriculture is used in French, Italian, Portuguese; ecological agriculture in German, Danish, Spanish, Romanian; and the organic farming in English.

Biodynamic farmers believe in the events and the role of cosmic influences, first the Moon position, and of the other planets, which exert an influence on the soil and on plants. This takes into account and several variants are found:

- The Moon effect on plants

- Muller- Ruch biological variant

- Lemaire-Boucher biological variant

- Organic variant
Worldwide, has outlined a new requirement, quite strong, which turned into a real movement to obtain food products through clean technologies, nature friendly, clean without chemicals. (Altieri, 1987; Munteanu et al., 2008; Roman et al., 2008).

In recent years, this type of agriculture began to grow in importance increasingly greater, both due to increasing organically cultivated areas and by increasing the number of producers and consumers.

If at first were around $15 \mathrm{EU}$ countries with an area of 3.8 million hectares, making a total of 130000 farms in 2009 has reached a total of 27 countries and a surface allocated to organic farming of approximately 8.3 million hectares, almost 220000 managed by producer.

Area occupied by organic agriculture worldwide was in 2004, of 23 million hectares, the largest areas being cultivated in Australia (10.5 million hectares), Argentina (3.2 million hectares) and Italy (1, 2 million hectares), according to a SOEL study, quoted by Rompres and www. smartfinancial.ro.

In the European Union, including Romania and Bulgaria, EFTA countries (Iceland, Liechtenstein, Norway, Switzerland), Turkey, BosniaHerzegovina, Croatia and Yugoslavia, there are more than five million hectares in organic farming, which corresponds to 2 percent of all agricultural land.

In terms of area cultivated in organic farming from the total agricultural area in the European Union stands Austria ranked first with 11.30\%, Switzerland $9.70 \%$, Italy $7.94 \%$, Denmark 6.51 \%, Sweden 6.30 \%, Czech Republic 5.06 \%, France $1.40 \%$. The surfaces under one percent are grown in Ireland, Slovenia, Greece, Poland, Slovenia and Yugoslavia.

The interest in organic products is gaining more ground in the European market. One of the largest markets in 2010 was Germany with around 5.9 billion followed by France with approximately 3.3 billion and the UK with around 2.2 billion euros.

Organic farming is a dynamic system in Romania with a average weighted rate of annual growth of approximately $20 \%$.

So, in recent years, Romania has registered a rapid and constant growth rate of the agricultural areas and the number of operators who have joined the environmental standards, and through 2014- 
2020 National Rural Development Programme can be obtained compensation for passage to organic farming. In 2012, the certificates areas reached 288.261 ha $(+268 \%)$, representing $2.1 \%$ of the utilized agricultural area of the country and the number of certified operators has increased 4.6 times compared to 2006. Between 2006-2012, the most spectacular growth was recorded in the areas "in conversion” segment (+ 436\%), especially in the last two years, showing that support through payments to farmers under the Rural Development Programme stimulates consistent initial stages of development of the sector environmentally friendly. If the average rate of the previous years 2006-2012 will be maintained, Romania will exceed ease in 2020, 4\% of the country's agricultural area used for organic farming, according to data published by the National Network for Rural Development (NRDN). Romanian organic market is only in an early stage of development, lacking reliable data on the size. Although organic agriculture is in a slight increase, it represents a small percentage of the total consumption of food products. In 2011, the sales of organic products reached approximately 1\% of the entire retail market in Romania, according to estimates of associations. In the same year, exports registered a total of 200 million euro (twice higher than in the previous year), while the domestic market has reached 80 million, with a constant annual increase of $20 \%$. However, most of the domestic consumption is covered by imports, while Romania is still a net exporter of raw organic goods. Since the processing sector is underdeveloped (in fact, the entire supply chain for organic products is still unbound), many certified products are sold as conventional products.

However, the availability of organic products has significantly improved in the last two years, mainly due to the interest of retailers. Today, nearly all major retail chains (supermarkets, hypermarkets) shows on sale organic products and are the most important distribution channels of certified products in Romania. The production and market positive trends in organic products were recognized at the largest annual event of the European ecological agriculture, Biofach Fair in Nuremberg, where Romania was nominated as the „Land of 2013". In the 2007-2013 programming period, the support for organic farming was part of the 214 agri-environment measure. This measure was used only for the payment of maintaining

Tab. 1. The operators and areas dynamics in organic farming

\begin{tabular}{|c|c|c|c|c|}
\hline Indicator & 2010 & 2011 & 2012 & 2013 \\
\hline $\begin{array}{l}\text { Number of certified operators in organic } \\
\text { farming }\end{array}$ & 3155 & 9703 & 15544 & 15194 \\
\hline Total surface in organic farming (ha) & 182705.7 & 229945.67 & 288260.83 & 301148.1 \\
\hline Cereals (ha) & 72297.78 & 79166.95 & 105148.5 & 109105.3 \\
\hline $\begin{array}{c}\text { Dried and protein legumes for the grain } \\
\text { production (including seeds and cereal and } \\
\text { legumes mixtures) (ha ) }\end{array}$ & 5560.22 & 3147.36 & 2764.04 & 2397.34 \\
\hline Total tuber and root plants (ha) & 504.36 & 1074.981 & 1124.915 & 740.75 \\
\hline Industrial crops (ha) & 47815.07 & 47879.68 & 44788.73 & 51770.78 \\
\hline Plants harvested green (ha) & 10325.4 & 4788.49 & 11082.93 & 13184.14 \\
\hline Other crops on arable lands (ha) & 579.61 & 851.44 & 27.77 & 263.95 \\
\hline Legumes (ha) & 734.32 & 914.08 & 896.32 & 1067.67 \\
\hline Permanent crops (ha) orchard and vines & 3093.04 & 4166.62 & 7781.33 & 9400.31 \\
\hline Permanent crops (ha) pastures and hayfields & 31579.11 & 78197.51 & 105835.57 & 103701.5 \\
\hline Uncultivated land (ha) & 10216.78 & 9758.554 & 8810.734 & 9516.33 \\
\hline 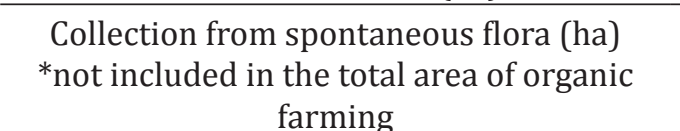 & 77294.35 & 338051 & 1082138 & 944546.2 \\
\hline
\end{tabular}


green practices on farmland (including fodder), annual vegetables (including mushrooms and potatoes), medicinal and perennial plants (orchards and vineyards). The support for farms in conversion was provided under 68 Article of Council EU Regulation No. 73/2009.

The labelling of organic products must be done respecting a certain content, a logo specific to the controlled organic products, registered at the State Office for Inventions and Trademarks, issued and applied on the basis of the certification system, indicating that the respectively product complies with the organic production rules (Roman et al., 2008; Stoian 1996)

\section{MATERIALS AND METHODS}

The aim of this paper is to study the consumers' attitude and preferences for medicinal and aromatic herbs.

Data for this study were collected using a questionnaire on paper that was filled in by the respondents themselves. The questionnaire consists of two parts: the first part includes 16socio-demographic questions (age, gender, area, income groups, marital status, etc.) and the second part includes 35 questions related to respondents' attitude and preferences associated to the use of medicinal and aromatic herbs. The answers to the questions related to consumers 'preferences are assessed on a five points scale (Strongly agree, Agree, Neither agree nor disagree, Disagree, Strongly disagree), while the opinion of the respondents regarding the use and growth of aromatic and medicinal plants is assessed on a dichotomous ( $\mathrm{Yes} / \mathrm{No})$ scale.

The survey was carried out both at a local AGRALIM Farmers Trade Show who is the most important event in the North-Eastern Region of Romania and is dedicated to farmers, producers, entrepreneurs, researchers and agricultural professionals in the area which exploit one of the most important agricultural areas of Romania.

AGRALIM is organized in partnership with U.S.A.M.V. (University of Agricultural Sciences and Veterinary Medicine) Iasi and it takes place takes place on field, on a 10 ha area, on the agricultural exhibition platform Ezareni.

The size of the sample surveyed at the AGRALIM Farmers Trade Show is of 91 respondents, and the sample from the USAMV-Iasi is equal to 32 respondents.
The data were processed with SPSS version 21 software.

\section{RESULTS AND DISCUSSIONS}

The structure of the sample (Fig.1) according to the social and demographic questions shows that most of the respondents are male (61.8\%). The dominant age group for the surveyed sample is the group 26-40 years (42.3\%). The majority of the respondents are from the urban area $(80.5 \%)$ and they have attained tertiary education (84.6\%). The monthly income of more than half of the surveyed persons is higher than $1500 \mathrm{RON} *$.

The results of this survey show that the respondents are satisfied using products made of medicinal and aromatic herbs. On a scale from 1 (Not at all satisfied) to 10 (Very much satisfied), the average score is 6.31. The percentage of respondents that declared to be satisfied (scores higher than the average) is of $45.6 \%$, while the percentage of persons that are less satisfied with this type of products (scores lower that the average) is $42.3 \%$. Furthermore, it can be noticed that women are more satisfied (women average score is 6.86) than men (men average score is 5.95) using products made of medicinal and aromatic herbs (Fig.3).

Moreover, women use more frequently than men medicinal herbs (Fig. 2). If $23.4 \%$ of the surveyed women declare to use these products daily or several times a day, the percentage of men is only $13.2 \%$. It can be seen that a high percent of male respondents $(44.7 \%)$ have used medicinal herbs only occasionally (Fig. 4).

The majority of the respondents are in favor of the growth of medicinal herbs in organic farming. Thus, $87.8 \%$ of the overall sample said "Yes" when asked if they consider compulsory the growing of medicinal plants in organic farms. However, $10.6 \%$ of the respondents are against this idea (Fig.5.). More than half of the respondents $(64.2 \%)$ consider themselves as consumers of products made of organic medicinal and aromatic herbs. In contrast, a very small percentage of the respondents $(8.9 \%)$ are producers of organic medicinal and aromatic herbs (Fig 5).

The majority of the respondents prefer wild harvesting of medicinal and aromatic plants compared to the ones produced through cultivation (Fig.6). Thus, $67.8 \%$ of the interviewed persons are in favor of (Agree and Strongly agree) 
wild harvesting. The prevalence of the persons that agreed on this issue can be noticed both for women and men. The attitude towards the Romanian vs. foreign products is reflected by more numerous answers that are in favor of the Romanian products. Consequently, 32.8\% of the respondents agree and strongly agree with the opinion that imported products made of organic medicinal and aromatic herbs are less good than the Romanian products (Fig. 7).

The percentage of people that disagree and strongly disagree is $18.5 \%$. It is worth noting that a large part of the respondents $(48.7 \%)$ that are not sure about the quality of the Romanian products

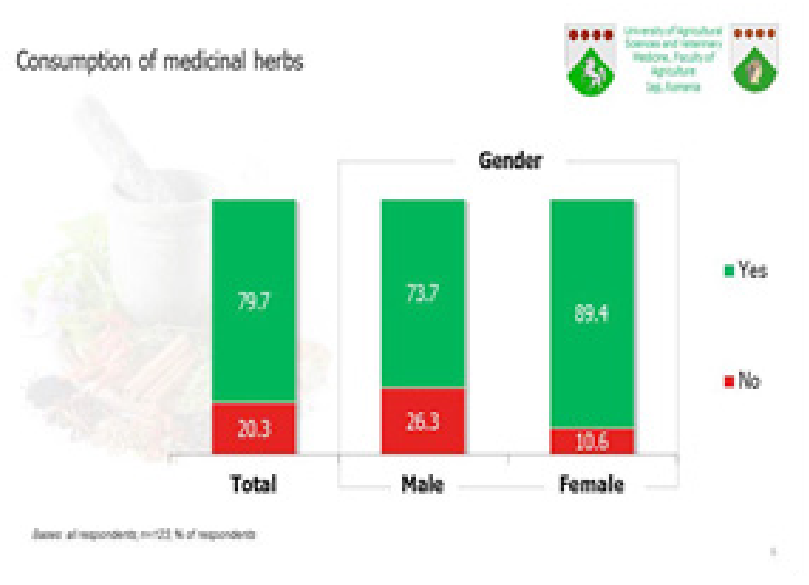

Fig. 1. The structure of the sample

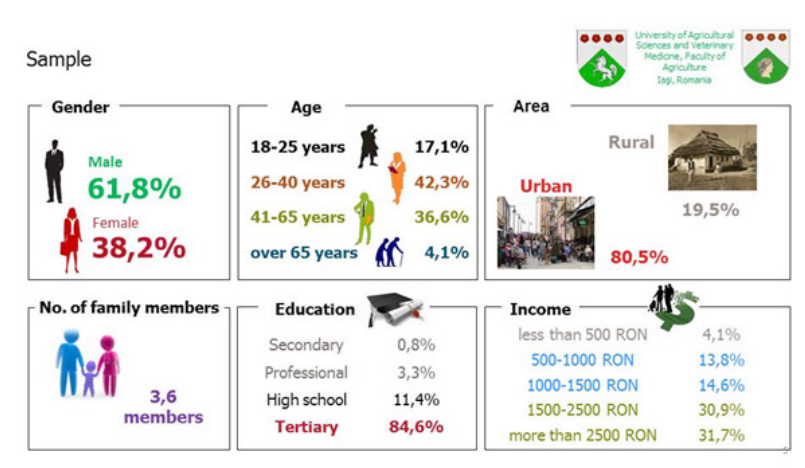

Fig.2. Consumption of medicinal herbs

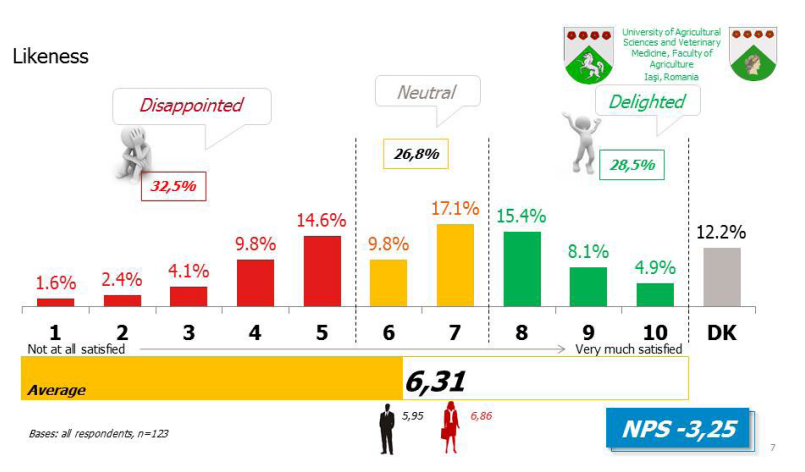

Fig.3. Likeness

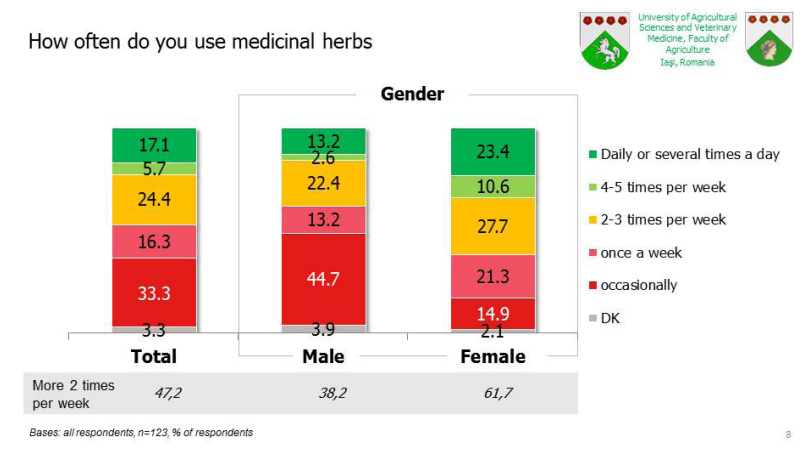

Fig.4. How often are used medicinal herbs

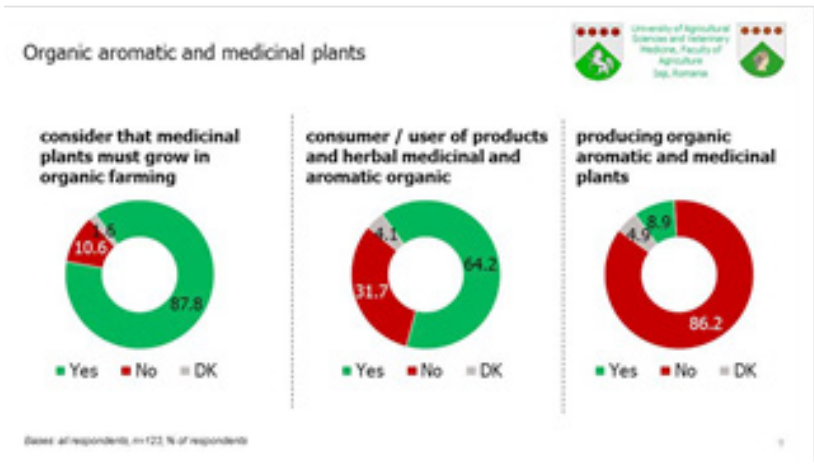

Fig.5. Organic aromatic and medicinal plants 
made of organic medicinal herbs as compared to other products from import. There are differences by gender regarding the opinion on the Romanian vs. imported products, as more women than men agree that imported products are less qualitative than Romanian ones, and also there are fewer women than men that don't have a polarized opinion, either agree or disagree. (Fig.8-14).

\section{CONCLUSION}

This study aimed at systematizing the existing points of view concerning ecological agriculture in the context of medicinal plants cultivation. The analysis of the results obtained after the administration of the questionnaires aimed to emphasize the medicinal and aromatic plants should be grown organically, and, furthermore, to

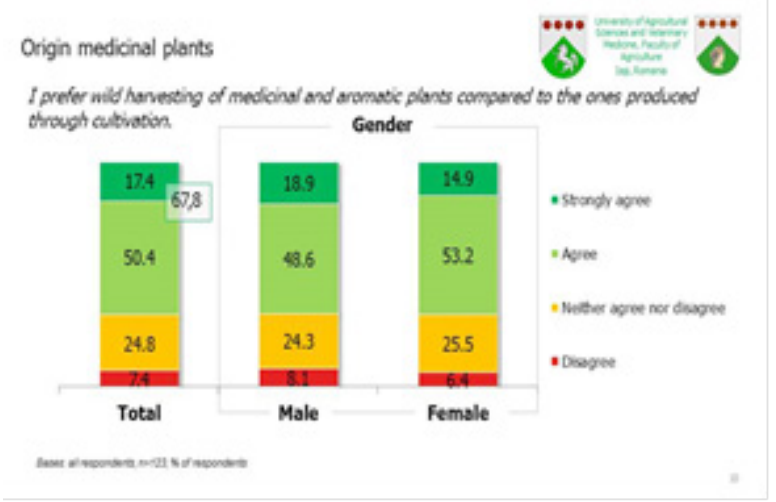

Fig.6. Origin medicinal plants

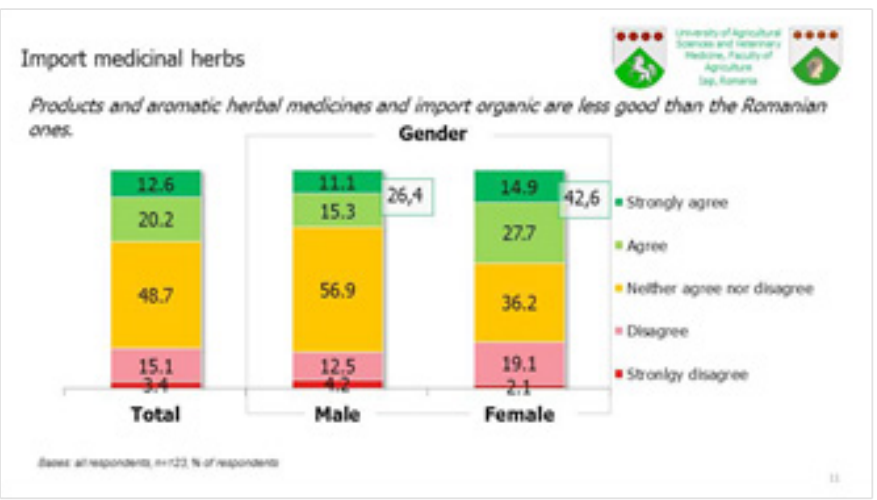

Fig.7. Import medicinal herbs

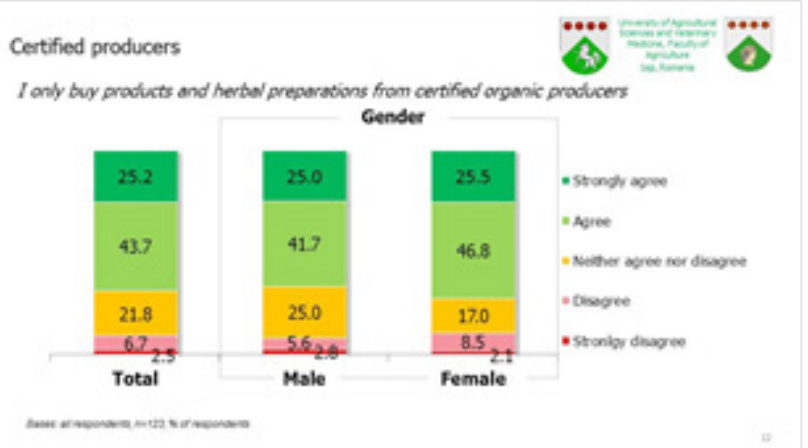

Fig.8. Certified producers

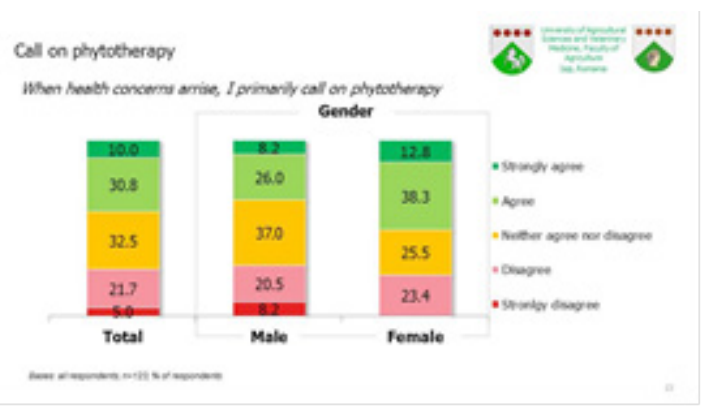

Fig.9. Call on phytotherapy

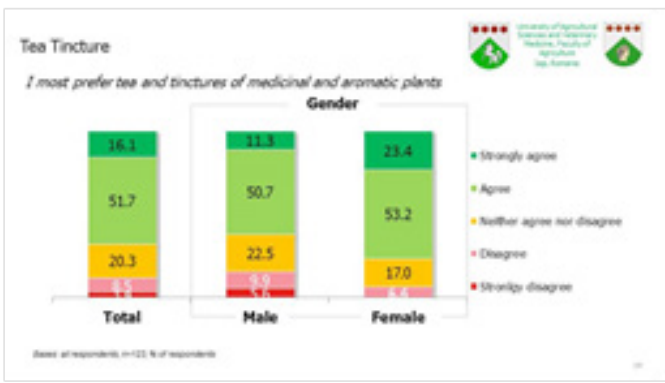

Fig.10. Tea and Tincture 


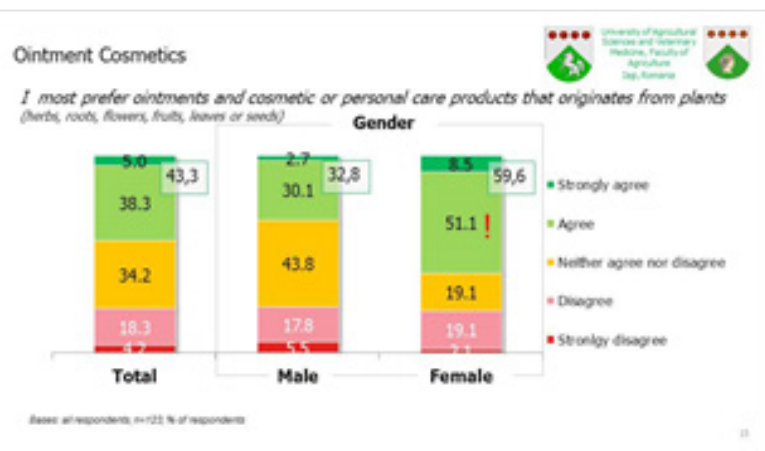

Fig.11. Ointment and Cosmetics

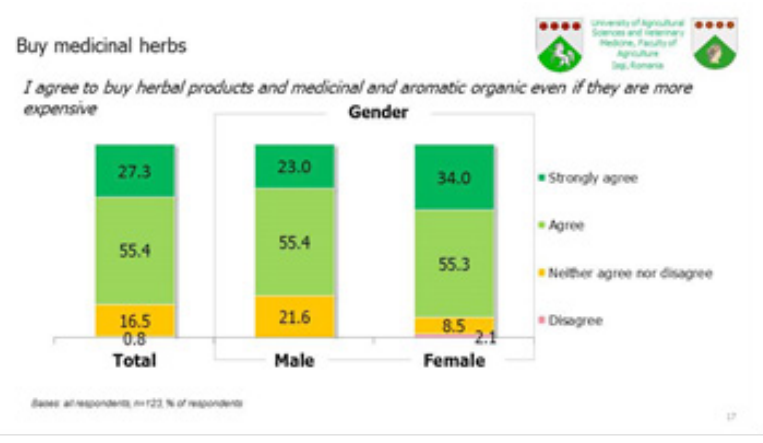

Fig.13. Agrement to buy medicinal herbs organic

emphasize the organic products from medicinal and aromatic plants have a good position in public opinion.

However, in the last resort, we believe that the relevance and the utility of this paper also depends on the extent to which it will contribute to the improvement of diverging discussions, being at least a landmark and the embodiment of some concrete ample actions specific to organic farming and medicinal herbs.

\section{REFERENCES}

1. Altieri M.A. (1987). Agroecology:the Scientific Basis of Alternative agriculture. Intermediare Technology Publications, London.

2. Davidescu D., Davidescu Velicia (1994). Agricultura biologică - o variantă pentru exploatațiile mici și mijlocii, Editura Ceres, București.

3. Roman, Valentin, Gheorghe, Gavril Morar, Teodor Robu, Marin Ştefan, Valeriu Tabără (2012). Fitotehnie - Vol.

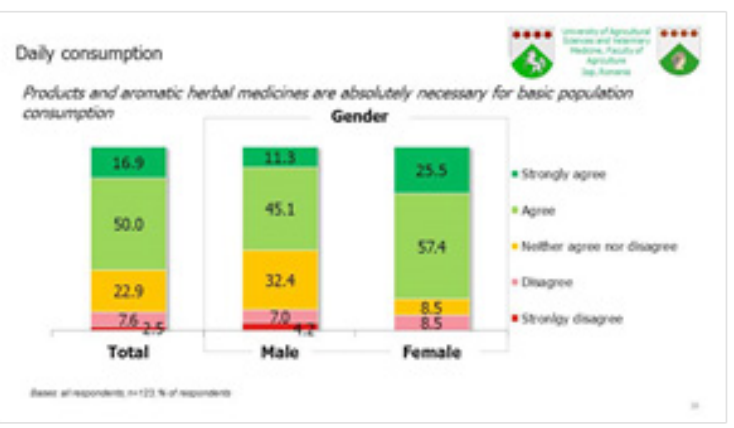

Fig.12. Daily consumption

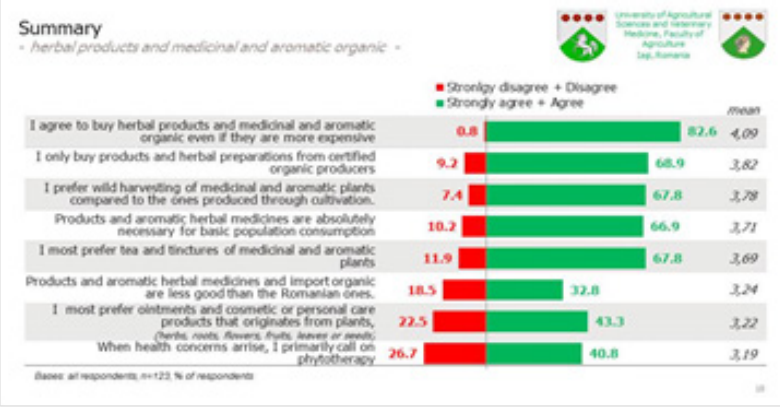

Fig.14. Agrement to buy herbal products

II - Plante tehnice, medicinale si aromatice, Editura Universitară.

4. Munteanu N., Bohatereț V., Stoleru V. (2008). De la agricultura convențională la agricultura ecologică, Editura STEF, Iași.

5. Robu,Teodor, Constantin Milică. (2004). Plante medicinale autohtone, Editura Institutul European.

6. Roman G.V, Toader Maria, Epure Lenuța Iuliana, Ion V., Bășa A.G. (2008). Cultura plantelor medicinale și aromatice în sistem ecologic, Editura Ceres, București.

7. Stoian L. (1996). O alternativă - agricultura biologică, Hortus, nr. 4, Societatea Română a Horticultorilor.

8. www.bioma.ro.

9. http://www.agriculturae.ro/index.php/agriculturaecologica/tehnologii-ecologice/153-culturile-bio-deplante-medicinale.html.

10. ht t p : / / w w w. hollandfarming.ro/produs / BIOSTIMULATORI/Cropmax.

11. www.SMARTfinancial.ro. 